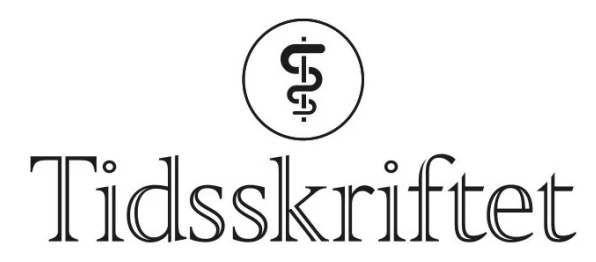

DEN NORSKE LEGEFORENING

\title{
Om dødshjelp for meningsfeller
}

\author{
ANMELDELSER
}

LARS ØYSTEIN URSIN

Førsteamanuensis i etikk

Norges teknisk-naturvitenskapelige universitet

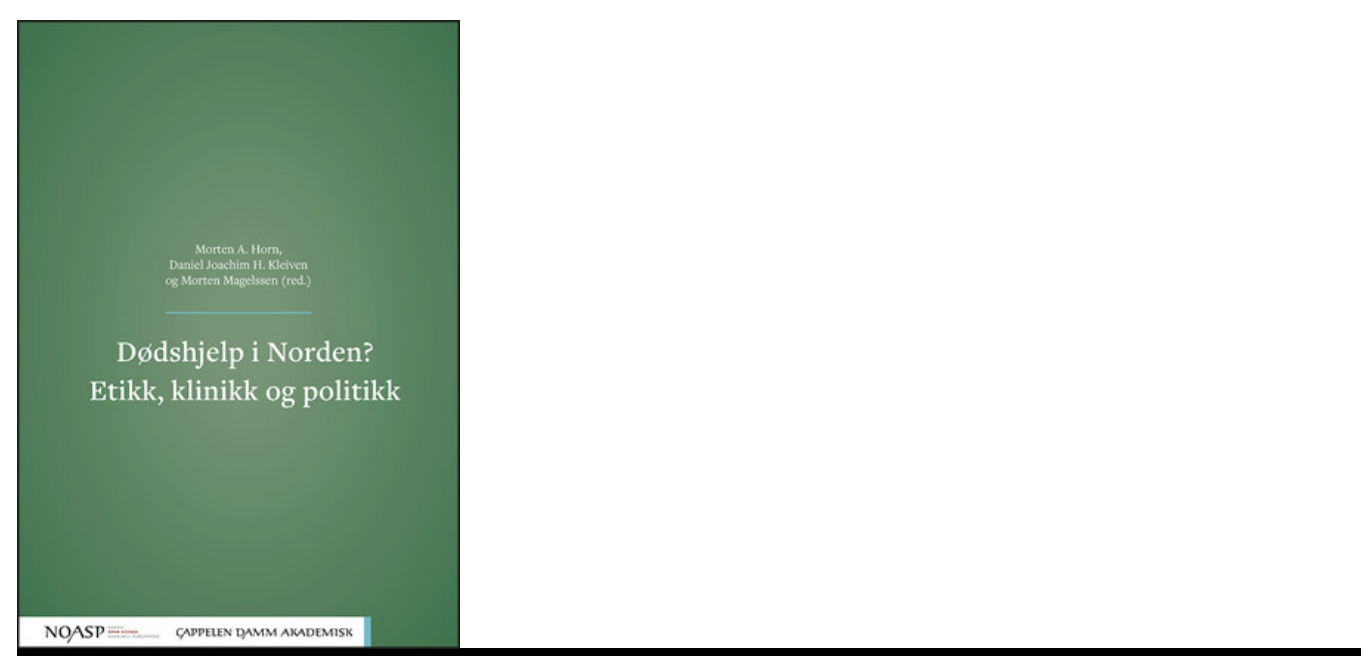

Morten A. Horn, Daniel Joachim H. Kleiven, Morten Magelssen, red.

Dødshjelp i Norden?

Etikk, klinikk og politikk. 316 s. Oslo: Cappelen Damm Akademisk, 2020. Pris NOK 379, tilgjengelig gratis på nett

ISBN 978-82-02-67764-0

I 2015 oppsummerte Søren Holm - en av bidragsyterne i antologien Dødshjelp i Norden?40 års debatt om dødshjelp i spaltene til tidsskriftet Journal of Medical Ethics. Holm skrev at debattens hovedargumenter kom tidlig på plass, og at et trekk ved den videre dødshjelpdebatten var at mange av tidsskriftartiklene blandet etisk analyse med politisk aktivisme. En slik politisk dynamikk kan ses som en naturlig følge av den etiske debattens statiske karakter.

Denne antologien faller greit inn under en slik karakteristikk. Allerede på vaskeseddelen proklameres det at boka har en «kritisk innstilling til legalisering», og at «hovedvekten ligger på argumenter som taler mot legalisering». Boka har slik ikke så mye et etisk, som et 
politisk siktemål: Nemlig å gi en samling argumenter og beskrivelser som alle peker mot et forbud mot dødshjelp. En kunne med fordel satt «Nei til» i begynnelsen av tittelen, og tatt vekk spørsmålstegnet til slutt.

Boka er gjennomgående velskrevet og lettfattelig, og har kapitler på norsk, dansk og svensk med ordforklaringer. Slik gir boka en prisverdig anledning til å opprettholde det felles skandinaviske språkrommet.

I boka fremstår ikke tittelspørsmålet om dødshjelp som et vanskelig etisk spørsmål. Bidragsyterne i boka er tilsynelatende skjønt enige om at dødshjelp bør forbys, og graviterer gjennomgående og som lovet mot det som peker mot forbud. Bidragene dreier seg først og fremst om å vise hvorfor og hvordan vi etisk, sosialt, medisinsk og politisk best klarer oss uten dødshjelp.

Om alt dette står det stort sett fine og fornuftige ting, og fortjenstfullt løftes det kliniske perspektivet frem. Men hadde boken åpnet for (og kommunisert godt med) flere synspunkter på sine tema, hadde boken (inkludert det som allerede står der) blitt mye mer opplysende, interessant - og konstruktivt. Motstemmer holdes nå på behagelig avstand, så mens en leser denne boken, fortoner det seg i grunn som en gåte hvorfor noen ønsker å tillate dødshjelp, og at dødshjelp har blitt diskutert i årtier.

Det etiske spørsmålet om dødshjelp blir derfor aldri brennende. Som leser speider en forgjeves etter diskusjoner hvor en får frem hvordan vektige hensyn står mot hverandre, hvilke muligheter og utfordringer ulike praksiser og perspektiver gir, og hvor konklusjonene langt fra er gitt.

Publisert: 25. mai 2021. Tidsskr Nor Legeforen. DOI: 10.4045/tidsskr.21.0179

(C) Tidsskrift for Den norske legeforening 2023. Lastet ned fra tidsskriftet.no 26. april 2023. 